\title{
ע Muutoksia ruokavalinnoissa COVID-19-pandemian aikana: Kansainvälisen Corona Cooking Survey -tutkimuksen tuloksia Suomesta
}

COVID-19-pandemian aikaiset rajoitustoimet muuttivat ihmisten arkisia käytäntöjä monin tavoin. Tarkastelemme artikkelissamme, millaisia muutoksia kevään 2020 rajoitustoimet aiheuttivat ruokavalinnoissa ja aterioiden valmistamisessa käyttäen terveellisiä raaka-aineita sekä miten sosioekonomiset ja muut taustatekijät, kuten koettu psyykkinen rasitus ja etätyö, olivat yhteydessä tapahtuneisiin muutoksiin.

Analysoimme kansainvälisessä Corona Cooking Survey -hankkeessa Suomessa kerättyä syömistä ja ruoanlaittoa tarkastelevaa kyselyaineistoa. Sosiaalisessa mediassa jaettuun kyselyyn vastasi touko-kesäkuussa 2020 yhteensä 744 Suomessa asuvaa 19-85-vuotiasta. Kyselyn vastaajat eivät ole väestöä edustava otos, sillä suurin osa vastaajista oli naisia (91 \%) ja korkeakoulututkinnon suorittaneita $(81 \%)$. Kuvaamme vastaajien raportoimia muutoksia yhteensä 19 ruoka-aineen käytön useudessa sekä aterioiden valmistamisessa terveellisistä raaka-aineista. Multinomiaalisissa logistisissa regressiomalleissa tarkastelemme terveellisistä raaka-aineista tehtyjen aterioiden valmistuksessa sekä viiden erilaisen ruoka-aineen käytössä tapahtuneisiin muutoksiin yhteydessä olevia tekijöitä.

Kaikkien ruoka-aineiden osalta yli puolet vastaajista raportoi, ettei kulutus ollut muuttunut. Eniten lisääntyi makeiden naposteltavien (29\% raportoi syövänsä aikaisempaa useammin) ja suolaisten naposteltavien (21\%) sekä valkoisen leivän, pastan ja viljojen (21\%) käyttö ja harventui liha-, siipikarja-, kala- tai kasvisjalosteiden (34\%), palkokasvien $(29 \%)$ ja pähkinöiden (27\%) käyttö. Regressiomallien tulosten mukaan useimmilla taustatekijöillä ei ollut yhteyttä muutoksiin ja selittävät tekijät vaihtelivat eri ruoka-aineissa. Koettu psyykkinen rasitus oli yhteydessä todennäköisyyteen kuluttaa aiempaa useammin makeita naposteltavia, sokeroituja juomia ja alkoholijuomia. Etätyö oli yhteydessä todennäköisyyteen syödä aiempaa harvemmin kasviksia ja useammin suolaisia naposteltavia, mutta myös todennäköisyyteen valmistaa aiempaa useammin aterioita terveellisistä raaka-aineista. Tulokset viittaavat siihen, että pandemia on lisännyt välipalaistumista. Jatkotutkimusta tarvitaan väestöä edustavilla otoksilla syömisrutiinien pidempiaikaisista muutoksista ja niiden mahdollisesta muuttumisesta terveellisemmiksi tai epäterveellisemmiksi tottumuksiksi eri väestöryhmissä.

ASIASANAT: Covid-19-rajoitustoimet, Covid-19-pandemia, ruokavalinnat, kyselytutkimus

LAURA SALMIVAARA, MARI NIVA, KAISA TORKKELI, JOHANNA MÄKELÄ, ANNUKKA VAINIO 


\section{YDINASIAT}

- Aikaisempien tutkimusten perusteella tiedetään, että stressi vähentää terveellistä syömistä.

- Covid-19-pandemia on lisännyt syömisen välipalaistumista.

- Psyykkinen rasitus oli yhteydessä makeiden naposteltavien, sokeroitujen juomien ja alkoholijuomien käytön lisääntymiseen.

- Etätyö oli yhteydessä kasvisten käytön vähentymiseen sekä suolaisten naposteltavien käytön lisääntymiseen.

- Lisätutkimusta tarvitaan koronapandemian aiheuttamista pitkäaikaisista muutoksista ruoankäytössä väestötasolla.

\section{JOHDANTO}

Vakavaa hengityselininfektiota aiheuttava koronavirus (COVID-19) levisi maailmanlaajuisesti pandemiaksi maaliskuussa 2020. Suomessa maan hallitus päätti 16. maaliskuuta 2020 valmiuslakiin perustuen ryhtyä ihmisten kontakteja vähentäviin toimiin. Tavoitteena oli koronaviruksen leviämisen estäminen ja terveydenhuollon ylikuormituksen välttäminen. Käytännössä tämä tarkoitti yhteiskunnan toimintojen merkittävää rajoittamista, mikä edelleen vaikutti suomalaisten arkeen, liikkumiseen, työssäkäyntiin ja talouteen. Koulut siirtyivät etäopetukseen ja alle kouluikäisiä lapsia suositeltiin hoidettavan kotona. Myös liikuntapaikat ja julkiset tilat suljettiin. Etätyön tekemistä suositeltiin kaikille työntekijöille, joille se oli mahdollista. Noin $60 \%$ suomalaisista työntekijöistä siirtyi etätyöhön, johon tyytyväisyys oli EU-maiden vertailussa korkealla $(1,2)$. Yli 70-vuotiaita kehotettiin pysyttelemään karanteenia vastaavissa olosuhteissa eli mahdollisuuksien mukaan olemaan tapaamatta muita kuin samassa taloudessa asuvia (3). Ravitsemisliikkeet suljettiin ja ainoastaan ruoan ulosmyynti oli mahdollista (4). Myöhemmin maaliskuun loppupuolella liikennettä Uudenmaan maakunnan ja muun Suomen välillä rajoitettiin viruksen leviämisen estämiseksi. Käytännössä Suomi suljettiin maaliskuun 18. päivästä kesäkuun 16. päivään saakka. Rajoitustoimista kärsivät yritykset joutuivat lomauttamaan ja irtisanomaan työntekijöitään, mikä vaikutti jopa joka viidenteen suomalaiseen kotitalouteen (5).

Poikkeustoimilla niin Suomessa kuin muualla maailmassa oli keväällä 2020 vaikutuksia paitsi ravitsemispalveluita tarjoaviin yrityksiin myös laajasti elintarvikkeiden kulutukseen eri väestöryhmissä (ks. esim. 6-8). Muutos oli nopea, ennakoimaton ja laaja. Suomessa poikkeuksellinen tilanne vaikutti päivittäin koulussa ruokaileviin koululaisiin ja ravitsemispalveluita käyttäviin työssäkäyviin. Koulu-, henkilöstö-, lounas- ja muiden ruokaravintoloiden suljettua ovensa kotitalouksien ruokaostot painottuivat vähittäiskauppoihin ja ruoan kulutus sekä valmistus siirtyivät ravitsemisliikkeistä koteihin. Tällaiset muutokset saattavat vaikuttaa myös syömisen terveellisyyteen, sillä tutkimusten mukaan työssäkäyvistä aikuisista henkilöstöravintoloissa ruokailevat valitsevat aterialleen useammin ravitsemussuositusten mukaisesti kasviksia ja kalaa verrattuna esimerkiksi eväitä syöviin tai kotona syöviin (9). Pandemian rajoitustoimien aikana ravitsemispalvelujen osittainen sulkeutuminen ja käytön vähentyminen loivat kotitalouksille uusia vaateita koskien sekä ruokailun terveellisyyttä että sen järjestämistä etäkoulussa ja -työssä oleville perheenjäsenille (ks. esim. 10).

Rajoitustoimien alussa ilmeni huolta ruoan riittävyydestä, mikä näkyi julkisuudessakin huomiota herättäneenä hamstrauksena. Mediatietojen mukaan kotitaloudet varastoivat pakasteita tai hyvin säilyviä elintarvikkeita, kuten kuivatuotteita, säilykkeitä, makeisia ja olutta, mikä aiheutti lyhytaikaisia toimitusvaikeuksia keskusliikkeille (esim. 11). Samaa tapahtui myös muissa maissa $(6,7)$. Erityisesti hedelmien, vihannesten, jauhojen ja maitotuotteiden mutta myös suolaisten ja makeiden naposteltavien kulutus kasvoi Euroopassa pandemian alussa (12). Suomessakin kulutustilastot osoittavat, että varsinkin kala-, äyriäis-, marja- ja hedelmäpakasteiden, riisin, pastan, jauhojen ja säilöttyjen vihannesten kulutus kasvoi pandemian alkuvaiheessa (13).

Kansainvälisten tutkimusten mukaan ruokatottumukset muuttuivat keskimäärin epäterveellisemmiksi ja ruokavalion ravitsemuksellinen laatu heikkeni (14). Syömisen kontrolli väheni, syöty ruoka oli epäterveellisempää ja sitä syötiin määrällisesti enemmän $(15,16)$ niin välipalojen kuin pääaterioidenkin osalta (17). Erityisesti ns. lohturuoan syöminen lisääntyi $(18,19)$. Toisaalta itseraportointiin perustuvissa tutkimuksissa monet vastaajat ovat arvioineet, ettei heidän ruoankulutuksessaan tapahtunut pandemian alettua merkittäviä muutoksia (esim. 20) ja osalla muu- 
tokset ovat voineet olla myös terveyden kannalta myönteisiä $(18,15)$. Myös alkoholin kulutuksen muutoksista on saatu erisuuntaisia tuloksia (18, 15). Itseraportointiin perustuvan tutkimuksen mukaan muihin Euroopan maihin verrattuna suomalaiset eivät juurikaan muuttaneet ruoan käytön ja ruoanlaiton tapojaan pandemian alkuvaiheessa, vaikka täällä valmisruokien käyttöä lisättiin muita maita enemmän. (12.)

Pandemian aikana poikkeukselliset olosuhteet vaikuttivat myös muutoin ihmisten fyysiseen ja psyykkiseen terveyteen. Vaikka työssäkäyvien yöunet pidentyivät (21), univaikeudet lisääntyivät (22). Työmatkojen lisäksi muu terveyttä edistävä liikunta väheni (23). Varsinkin nuorilla aikuisilla pandemia-aikaan liittyi ahdistusta ja stressiä (24), jotka saattoivat olla yhteydessä huoleen pandemiasta tai omasta tai perheenjäsenten sairastumisesta, mutta myös työelämään ja talouteen liittyvään epävarmuuteen (25). Tutkimuksissa on havaittu pandemian kaiken kaikkiaan aiheuttaneen psyykkistä rasitusta (engl. psychological distress) ja mielenterveyden heikkenemistä $(26,19)$ sekä mahdollisesti lisänneen terveyden epätasa-arvoa. (vrt. 20).

Psyykkinen rasitus ja huolestuneisuus vaikuttavat ruokakäyttäytymiseen: psyykkisen rasituksen on todettu vähentävän terveellistä syömistä ja lisäävän epäterveellisten naposteltavien (ks. esim. 27, 18) sekä alkoholin (ks. esim. 28) kulutusta pandemian aikana. Koronapandemiaan liittyvien rajoitustoimien aikana Suomessa ei kuitenkaan toistaiseksi ole tutkittu, minkälaisia yhteyksiä etätyöllä, koetulla psyykkisellä rasituksella sekä sosiodemografisilla tekijöillä on ollut syömisen terveellisyyteen ja ruokavalintoihin.

\section{TAVOITE JA TUTKIMUSKYSYMYKSET}

Tämän tutkimuksen tarkoituksena on tuoda tietoa korona-ajan terveyttä ja hyvinvointia edistävien tai vähentävien ruokavalintojen taustoista. Tavoitteena on arvioida ja lisätä ymmärrystä sosiodemografisten ja poikkeusoloista johtuvien tekijöiden, kuten psyykkisen rasituksen ja kotona työskentelyn, yhteyksistä ruokavalintoihin ja aterioiden valmistamiseen terveellisiä raaka-aineita käyttäen. Tutkimuksen tavoitteena on vastata seuraaviin tutkimuskysymyksiin:

1) Miten ruokavalinnat ja aterioiden valmistaminen käyttäen terveellisiä raaka-aineita muut- tuivat koronapandemiaan liittyvien rajoitustoimien aikana keväällä 2020?

2) Miten sosiodemografiset taustatekijät (ikä, koulutus, kotitaloustyyppi, työssäkäynti sekä tulojen vähentyminen korona-aikana) sekä korona-aikana koettu psyykkinen rasitus, pyrkimykset toteuttaa terveellistä syömistä ja rajoitustoimien kesto olivat yhteydessä tapahtuneisiin syömisen muutoksiin?

\section{AINEISTO JA MENETELMÄT}

Tutkimus on osa kansainvälistä Corona Cooking Survey -tutkimushanketta, jota koordinoi ja jonka kyselylomakkeen suunnitteli Antwerpenin yliopiston tutkimusryhmä FOOMS (Food Media \& Society). Corona Cooking Survey -hanke (https:// coronacookingsurvey.com/) on 38 eri maassa ja useissa maanosissa yhtäaikaisesti toteutettu tutkimus ruoan ostamisen, ruoanlaiton, ruokailutottumusten sekä ruoanlaittoon liittyvän median käytön muutoksista pandemia-aikana (29). Tutkimuksen protokollan hyväksyi Antwerpenin yliopiston humanististen ja yhteiskuntatieteiden eettinen komitea. Kunkin osallistujamaan tutkijat käänsivät lomakkeen kysymykset omalle kielelleen, mikäli se oli muu kuin ranska, hollanti tai englanti. Suomessa hankkeen yhteistyökumppaneina olivat ja lomakkeen käänsivät suomeksi tämän artikkelin kirjoittajat.

\section{AINEISTON KERÄYS}

Aineisto kerättiin touko-kesäkuussa 2020 verkkolomakkeella käyttäen Qualtrics Survey -alustaa (www.qualtrics.com). Linkkiä kyselylomakkeeseen jaettiin tutkijoiden omissa verkostoissa sosiaalisen median (Twitter, LinkedIn, Instagram ja Facebook) sekä sähköpostin välityksellä. Lisäksi linkki julkaistiin useissa ruoanlaittoon liittyvissä suomenkielisissä Facebook-ryhmissä. Kyselylomake oli mahdollista täyttää joko suomeksi tai englanniksi.

Lomakkeella kysyttiin muun muassa ruokaostoksista, ruoka-aineiden käytön useudesta, ruoanlaitosta ja leipomisesta, syömisestä, vastaajan omista ruoanlaittotaidoista, ruoanlaiton esteistä sekä reseptien hankkimisesta ennen pandemiaan liittyviä rajoitustoimia ja niiden aikana. Lomake sisälsi myös kysymyksiä tunteista, jotka liittyivät ruoan ostamiseen, ruoanlaittoon ja pandemian aikaiseen psyykkiseen rasitukseen. Tässä 
artikkelissa hyödynnettiin lomakkeen kysymyksistä erityisesti niitä, jotka kuvaavat syömisen ja ruoanlaiton terveellisyyteen liittyvää toimintaa.

\section{AINEISTON KÄSITTELY}

Useimmissa lomakkeen kysymyksissä kysyttiin vastaajan omaa arviota ruokaan liittyvistä tottumuksista ja toiminnasta ennen rajoitustoimia ja rajoitustoimien aikana. Näiden ennen ja jälkeen -kysymysten tavoitteena oli saada käsitys tapahtuneista mahdollisista muutoksista. Niitä pandemian aikaisessa toiminnassa verrattuna pandemiaa edeltävään aikaan mitattiin kahdella toistuvalla kysymyksellä: "Ennen rajoitustoimenpiteiden voimaantuloa, kuinka usein yleensä teit seuraavia asioita?” ja "Tällä hetkellä (rajoitustoimenpiteiden ollessa voimassa), kuinka usein yleensä teet seuraavia asioita?” Tässä artikkelissa toimintaan liittyvistä muuttujista analysoidaan muuttujaa "Valmistin/valmistan aterioita kotona käyttäen terveellisiä raaka-aineita". Vastausvaihtoehdot esitettiin 7-portaisella useutta mittaavalla asteikolla: 1) en koskaan, 2) hyvin harvoin, 3) harvoin, 4) toisinaan, 5) usein, 6) hyvin usein, 7) joka kerta.

Lomakkeella kysyttiin myös muutoksista eri ruoka-aineiden käytössä. Mukana oli 19 eri ruoka-ainetta tai ruoka-aineryhmää (Taulukko 2). Tämäkin kysymys esitettiin kaksi kertaa: "Ennen rajoitustoimenpiteiden voimaantuloa/Tällä hetkellä rajoitustoimenpiteiden ollessa voimassa, kuinka usein nautit seuraavia ruokia ja juomia?”. Vastausvaihtoehdot esitettiin 7-portaisella asteikolla: 1) en (juuri) koskaan, 2) alle kerran viikossa, 3) kerran viikossa, 4) 2-4 kertaa viikossa, 5) 5-6 kertaa viikossa, 6) kerran päivässä, 7) vähintään kaksi kertaa päivässä.

Tilastollista analyysia varten edellisistä muuttujista muodostettiin ensin muutosmuuttujat vähentämällä ennen pandemiaa raportoidusta toiminnan useudesta tutkimushetkellä raportoitu useus. Tämän jälkeen muutosmuuttujat muunnettiin kolmiluokkaisiksi: toiminnan lisääntyminen (1), vähentyminen (-1) ja ei muutosta (0). Näin tehtiin tilastollisen mallinnuksen tulkinnan selkeyttämiseksi.

Pandemian aikaisen psyykkisen rasituksen mittaamiseen käytettiin Kesslerin ym. (30) mittaria. Mittarin sisältämistä kuudesta väitteestä ("Koen oloni toivottomaksi", "Koen oloni levottomaksi", "Koen, että kaikki vaatii ponnistelua",
"Koen oloni arvottomaksi", "Koen oloni hermostuneeksi" ja "Koen oloni niin masentuneeksi, että mikään ei piristä minua") muodostettiin analyysia varten psyykkistä rasitusta mittaava keskiarvomuuttuja (Cronbachin $\alpha=0,894$ ). Vastausvaihtoehdot esitettiin tässäkin 7-portaisella asteikolla: 1) en koskaan, 2) hyvin harvoin, 3) harvoin, 4) toisinaan, 5) usein, 6) hyvin usein, 7) koko ajan.

Vastaajat luokiteltiin iän mukaan neljään ryhmään: 1) 19-34-vuotiaat, 2) 35-50-vuotiaat, 3) 51-64-vuotiaat sekä 4) 65-vuotiaat ja sitä vanhemmat. Koulutustaso muutettiin analyysia varten kaksiluokkaiseksi muuttujaksi siten, että vaihtoehdot alempi korkeakoulututkinto, ylempi korkeakoulututkinto sekä lisensiaatin tai tohtorin tutkinto saivat arvon 0 (korkeakoulututkinto) ja peruskoulu/keskikoulu/kansakoulu ja ylioppilas- tai ammatillinen tutkinto saivat arvon 1 (ei korkeakoulututkintoa). Työssäkäynti-muuttuja muodostettiin yhdistämällä tiedot neljästä eri muuttujasta: työssäkäynnistä, osa-aikaisesta ja kokoaikaisesta työstä sekä etätyöstä. Kolmiluokkainen muuttuja muodostettiin seuraavasti: 0) osa- tai kokoaikainen etätyö, 1) osa- tai kokoaikatyö kodin ulkopuolella ja 2) työelämän ulkopuolella (työttömät, eläkeläiset, päätoimiset opiskelijat tai perhevapaalla olevat). Tulojen vähentyminen pandemian aikana oli kaksiluokkainen: 0) vastaajan tulotaso laskenut ja 1) vastaajan tulotaso ennallaan. Kotitaloustyypistä muodostettiin kolme luokkaa: 1) lapsiperheet (joissa alle 18-vuotiaita lapsia), 2) kahden tai useamman aikuisen taloudet sekä 3) yksin asuvat. Koronarajoitustoimien kesto vastaamisen hetkellä luokiteltiin neljään ryhmään: 1) enintään 4 viikkoa, 2) 5-7 viikkoa, 3) 8-10 viikkoa, ja 4) 11 viikkoa tai pidempi.

\section{TILASTOLLISET ANALYYSIMENETELMÄT}

Aineiston analysointiin käytettiin IBM SPSS Statistics 25 ohjelmaa. Muutoksia ruoka-aineiden käytön sekä terveellisistä raaka-aineista tehtyjen aterioiden valmistamisen useudessa ennen rajoitustoimia ja rajoitustoimien aikana mitattiin toistuvien mittausten varianssianalyysilla. Näin saatiin selville, missä ruoka-aineryhmissä oli tilastollisesti merkitseviä muutoksia.

Koska varianssianalyysista selviää ainoastaan raportoitujen muutosten tilastollinen merkitsevyys, terveellisistä raaka-aineista tehtyjen ate- 
rioiden valmistuksen sekä tarkasteluun valittujen ruoka-aineryhmien käytön muutoksiin yhteydessä olevia tekijöitä tarkasteltiin multinomiaalisen logistisen regressioanalyysin avulla. Multinomiaalinen logistinen regressioanalyysi on sopiva analyysimenetelmä silloin, kun selitettävässä muuttujassa on enemmän kuin kaksi luokkaa. Tämän tutkimuksen analyysi sisältää kuusi mallia, jotka on muodostettu seuraaville selitettäville muuttujille: 1) Aterioiden valmistaminen kotona käyttäen terveellisiä raaka-aineita sekä 2) kasvisten, 3) makeiden naposteltavien, 4) suolaisten naposteltavien, 5) sokeroitujen juomien ja 6) alkoholijuomien käyttö. Näistä ensimmäinen muuttuja kohdistuu ihmisten subjektiivisiin käsityksiin terveellisen ruoanlaiton useudesta kotitaloudessaan ennen rajoitustoimia ja niiden aikana. Ruoka-ainemuuttujia valitessamme nojasimme suomalaisiin ravitsemussuosituksiin (31), joissa varsinkin kasviksia, marjoja ja hedelmiä suositellaan syötäväksi päivittäin, kun taas harvemmin syötäviksi suositellaan erilaisia suolaisia ja makeita herkkuja sekä sokeroituja juomia. Myös lihavalmisteiden ja punaisen lihan käyttöä suositellaan vähennettävän. Alkoholia ei pitäisi nauttia päivittäin lainkaan tai ainakin sen käyttöä suositellaan rajoitettavan yhteen annokseen päivässä naisilla ja kahteen miehillä.

Muuttujat valittiin multinomiaalisiin malleihin siten, että mukaan saatiin niin päivittäin kuin harvemmin syötäväksi suositeltuja ruoka-aineita. Hedelmien ja marjojen sekä lihan käytössä ei havaittu tilastollisesti merkitseviä muutoksia, joten niitä ei otettu mukaan analyysiin. Selitettävissä muuttujissa tapahtuneita muutoksia analysoitaessa vertailuryhmäksi valittiin ne vastaajat, jotka eivät raportoineet muutosta lainkaan. Mallien muodostuksessa faktoreina käytettiin koulutustasoa, työssäkäyntiä, tulotasoa pandemia-aikana sekä kotitaloustyyppiä. Koska suurin osa vastaajista (91\%) oli naisia, sukupuolta ei otettu mukaan selittäväksi muuttujaksi. Kovariaatteina puolestaan käytettiin ikää, rajoitustoimien kestoa, terveellisyyden huomioon ottamista ruokavalinnoissa ("Tällä hetkellä (rajoitustoimenpiteiden ollessa voimassa) otan huomioon terveellisyyden ruokavalintoja tehdessäni”), luottamusta omiin taitoihin terveellisten aterioiden valmistamisessa ("Tällä hetkellä (rajoitustoimenpiteiden ollessa voimassa) luotan taitoihini valmistaa erilaisia terveellisiä aterioita”) sekä pandemian aikaista psyykkistä rasitusta edellä mainitulla keskiarvomuuttujalla. Kaikki faktorit ja kovariaatit lisättiin malleihin yhtä aikaa.

\section{TULOKSET}

Aineisto koostui 744 vastaajasta, joista naisia oli $91 \%$. Vastaajien mediaani-ikä oli 43 vuotta. Kaikkiaan $81 \%$ vastaajista oli suorittanut korkeakoulututkinnon ja $70 \%$ oli työelämässä joko osa- tai kokoaikaisesti. Vastaajista $17 \%$ ilmoitti tulotasonsa laskeneen pandemian aikana. Otos ei ole väestöä edustava, vaan painottuu voimakkaasti työssäkäyviin, korkeakoulutettuihin naisiin. Vaikka miesten ja sukupuolta määrittelemättömien osuus oli pieni (9\%), molemmat kategoriat päätettiin pitää aineistossa mukana, koska vastaajista lähes $98 \%$ vastasi tutkimushetkellä ruoan valmistamisesta yksin tai jonkun muun taloudessa asuvan kanssa. Myös terveellisyys ruoanlaitossa korostui aineistossa: $79 \%$ ilmoitti ottavansa usein, hyvin usein tai joka kerta huomioon terveellisyyden ruokavalintoja tehdessään ja $91 \%$ luotti vähintään usein taitoihinsa valmistaa erilaisia terveellisiä aterioita. Aineiston sosiodemografisten sekä muiden taustatekijöiden jakaumat on esitetty taulukossa 1.

\section{ERI RUOKA-AINEIDEN KÄYTÖN JA TERVEELLISISTÄ RAAKA-AINEISTA TEHTYJEN ATERIOIDEN VALMISTAMISEN MUUTOKSET KEVÄ̈̈LLÄ 2020}

Taulukosta 2 nähdään, että kotona terveellisistä raaka-aineista tehtyjen aterioiden valmistamisen useuden lisääntymisestä pandemian rajoitustoimien aikana raportoi $34 \%$ vastaajista ja vähentymisestä $13 \%$. Vastaajista $53 \%$ ei raportoinut tämän muuttujan suhteen muutoksia. Ruoka-aineissa vastaajat raportoivat suurimpia käytön useuden lisäyksiä makeiden $(29 \%)$ ja suolaisten (21\%) naposteltavien sekä valkoisen leivän, pas$\tan$ ja viljojen $(21 \%)$ osalta. Eniten vastaajat kertoivat vähentäneensä liha-, siipikarja-, kala- tai kasvisjalosteiden (34\%), palkokasvien (29\%) ja pähkinöiden $(27 \%)$ käytön useutta. Vähiten muutoksia oli raportoitu sokeroimattomien juomien, kuten veden, kahvin ja teen (92\%), maidon (80\%) sekä kasvipohjaisten juomien (79\%) käyttöuseudessa. Terveellisistä raaka-aineista tehtyjen aterioiden valmistamisen sekä useuden muutosten jakaumat on esitetty taulukossa 2 .

Taulukosta 2 nähdään, että suurin osa vastaajista ei ollut muuttanut kysyttyjen ruoka-aineryhmien käyttöuseutta rajoitustoimien aikana 
Taulukko 1. Sosiodemografisten sekä muiden taustatekijöiden jakaumat

\begin{tabular}{|c|c|}
\hline \multicolumn{2}{|l|}{ Sukupuoli } \\
\hline Nainen & $676(90,1 \%)$ \\
\hline Mies & $56(7,5 \%)$ \\
\hline Muu & $12(1,6 \%)$ \\
\hline Ikä (keski-ikä, mediaani, keskihajonta) & $(43,13,133)$ \\
\hline $19-34$-vuotiaat & $180(24,2 \%)$ \\
\hline $35-50$-vuotiaat & $321(43,1 \%)$ \\
\hline $51-64$-vuotiaat & $179(24,1 \%)$ \\
\hline 65 -vuotiaat ja sitä vanhemmat & $64(8,6 \%)$ \\
\hline \multicolumn{2}{|l|}{ Koulutustaso } \\
\hline Ei korkeakoulututkintoa & $141(19,0 \%)$ \\
\hline Korkeakoulututkinto & $603(81,0 \%)$ \\
\hline \multicolumn{2}{|l|}{ Työssäkäynti } \\
\hline Osa- tai kokoaikainen etätyö & $426(57,3 \%)$ \\
\hline Osa- tai kokoaikatyö kodin ulkopuolella & $94(12,6 \%)$ \\
\hline Työelämän ulkopuolella & $224(30,1 \%)$ \\
\hline \multicolumn{2}{|l|}{ Tulotaso } \\
\hline Laskenut & $126(16,9 \%)$ \\
\hline Ennallaan & $618(83,1 \%)$ \\
\hline \multicolumn{2}{|l|}{ Kotitaloustyyppi } \\
\hline Lapsiperhe (<18-vuotiaita lapsia) & $266(35,8 \%)$ \\
\hline Kaksi tai useampi aikuinen & $330(44,5 \%)$ \\
\hline Yksin asuva & $148(19,9 \%)$ \\
\hline \multicolumn{2}{|l|}{ Rajoitustoimien kesto } \\
\hline Enintään 4 viikkoa & $32(4,3 \%)$ \\
\hline $5-7$ viikkoa & $451(60,6 \%)$ \\
\hline $8-10$ viikkoa & $250(33,6 \%)$ \\
\hline 11 viikkoa tai pidempi & $11(1,5 \%)$ \\
\hline
\end{tabular}

Tällä hetkellä (rajoitustoimien aikana) otan huomioon terveellisyyden ruokavalintoja tehdessäni

\begin{tabular}{ll}
\hline En koskaan & $9(1,2 \%)$ \\
Hyvin harvoin & $7(0,9 \%)$ \\
Harvoin & $14(1,9 \%)$ \\
Toisinaan & $129(17,3 \%)$ \\
Usein & $274(36,8 \%)$ \\
Hyvin usein & $238(32,0 \%)$ \\
Joka kerta & $73(9,8 \%)$
\end{tabular}

Tällä hetkellä (rajoitustoimien aikana) luotan taitoihini valmistaa erilaisia terveellisiä aterioita

\begin{tabular}{ll} 
En koskaan & $4(0,5 \%)$ \\
Hyvin harvoin & $4(0,5 \%)$ \\
Harvoin & $10(1,3 \%)$ \\
Toisinaan & $46(6,2 \%)$ \\
Usein & $181(24,3 \%)$ \\
Hyvin usein & $241(32,4 \%)$ \\
Joka kerta & $258(34,7 \%)$ \\
& \\
Psyykkinen rasitus (keskiarvomuuttuja) & \\
\hline $1-1,99$ & $228(30,6 \%)$ \\
$2-2,99$ & $206(27,7 \%)$ \\
$3-3,99$ & $207(27,8 \%)$ \\
$4-4,99$ & $85(11,4 \%)$ \\
$5-5,99$ & $15(2 \%)$ \\
$6-$ & $3(0,4 \%)$
\end{tabular}


Taulukko 2. Terveellisistä raaka-aineista tehtyjen aterioiden valmistamisen ja ruoka-aineiden käytön useuden muutosten jakaumat.

\begin{tabular}{|c|c|c|c|c|c|}
\hline Ruoka-aineet & $\begin{array}{l}\text { harvemmin } \\
\text { kuin ennen } \\
\text { rajoitustoimia }\end{array}$ & ei muutosta & $\begin{array}{l}\text { useammin } \\
\text { kuin ennen } \\
\text { rajoitustoimia }\end{array}$ & $\mathrm{F}$ & $\eta_{p}^{2}$ \\
\hline & $\mathrm{N}(\%)$ & $\mathrm{N}(\%)$ & $\mathrm{N}(\%)$ & & \\
\hline $\begin{array}{l}\text { Valmistin/valmistan aterioita kotona } \\
\text { käyttäen terveellisiä raaka-aineita **** }\end{array}$ & $96(12,9 \%)$ & $396(53,2 \%)$ & $252(33,9 \%)$ & 89,49 & 0,11 \\
\hline $\begin{array}{l}\text { Hedelmät ja marjat (tuoreena tai } \\
\text { pakastettuna) }\end{array}$ & $108(14,5 \%)$ & $515(69,2 \%)$ & $121(16,3 \%)$ & 0,05 & 0,00 \\
\hline $\begin{array}{l}\text { Kasvikset (tuoreena tai } \\
\text { pakastettuna) }{ }^{* * *}\end{array}$ & $139(18,7 \%)$ & $525(70,6 \%)$ & $80(10,8 \%)$ & 17,77 & 0,02 \\
\hline $\begin{array}{l}\text { Palkokasvit (esim. pavut, linssit, } \\
\text { kikherneet) }\end{array}$ & $213(28,6 \%)$ & $434(58,3 \%)$ & $97(13,0 \%)$ & 43,01 & 0,06 \\
\hline $\begin{array}{l}\text { Pähkinät (suolattomat) ja } \\
\text { pähkinälevite } * * *\end{array}$ & $202(27,2 \%)$ & $456(61,3 \%)$ & $86(11,6 \%)$ & 39,42 & 0,05 \\
\hline $\begin{array}{l}\text { Punainen liha (esim. nauta, sika, } \\
\text { lammas, hirvi, poro) }\end{array}$ & $75(10,1 \%)$ & $575(77,3 \%)$ & $94(12,6 \%)$ & 2,58 & 0,00 \\
\hline Siipikarjanliha & $88(11,8 \%)$ & $567(76,2 \%)$ & $89(12,0 \%)$ & 0,44 & 0,00 \\
\hline Kala*** & $126(16,9 \%)$ & $548(73,7 \%)$ & $70(9,4 \%)$ & 15,42 & 0,02 \\
\hline $\begin{array}{l}\text { Kasvisruokavaihtoehto (esim. tofu, } \\
\text { tempeh, } \\
\text { seitan) } * * *\end{array}$ & $166(22,3 \%)$ & $497(66,8 \%)$ & $81(10,9 \%)$ & 31,59 & 0,04 \\
\hline $\begin{array}{l}\text { Liha-, siipikarja-, kala- tai } \\
\text { kasvisjalosteet (esim. hampurilaiset, } \\
\text { makkarat, leikkeleet, paistetut ruoat, } \\
\text { levitteet jne.**** }\end{array}$ & $252(33,9 \%)$ & $401(53,9 \%)$ & $91(12,2 \%)$ & 77,92 & 0,10 \\
\hline Täysjyväleipä, -pasta, -viljat**** & $153(20,6 \%)$ & $480(64,5 \%)$ & $111(14,9 \%)$ & 17,47 & 0,02 \\
\hline $\begin{array}{l}\text { Valkoinen leipä, pasta, } \\
\text { viljat }\end{array}$ & $144(19,4 \%)$ & $443(59,5 \%)$ & $157(21,1 \%)$ & 0,16 & 0,00 \\
\hline $\begin{array}{l}\text { Makeat naposteltavat (esim. } \\
\text { makeiset, keksit, kakut, piirakat)**** }\end{array}$ & $96(12,9 \%)$ & $430(57,8 \%)$ & $218(29,3 \%)$ & 47,50 & 0,06 \\
\hline $\begin{array}{l}\text { Suolaiset naposteltavat (esim. } \\
\text { perunalastut, suolapähkinät)**** }\end{array}$ & $100(13,4 \%)$ & $487(65,5 \%)$ & $157(21,1 \%)$ & 14,56 & 0,02 \\
\hline Maito & $69(9,3 \%)$ & $596(80,1 \%)$ & $79(10,6 \%)$ & 0,06 & 0,00 \\
\hline $\begin{array}{l}\text { Muut maitotuotteet (esim. jogurtti, } \\
\text { juusto) }\end{array}$ & $93(12,5 \%)$ & $534(71,8 \%)$ & $117(15,7 \%)$ & 1,62 & 0,00 \\
\hline $\begin{array}{l}\text { Kasvipohjaiset juomat } \\
\text { (esim. manteli-, kaura, soija-, } \\
\text { riisijuoma)** }\end{array}$ & $97(13,0 \%)$ & $591(79,4 \%)$ & $56(7,5 \%)$ & 6,86 & 0,01 \\
\hline $\begin{array}{l}\text { Sokeroimattomat juomat (esim. vesi, } \\
\text { kahvi, tee) }\end{array}$ & $32(4,3 \%)$ & $683(91,8 \%)$ & $29(3,9 \%)$ & 2,93 & 0,00 \\
\hline $\begin{array}{l}\text { Sokeroidut juomat (esim. } \\
\text { virvoitusjuomat, sokerilla makeutettu } \\
\text { kahvi/tee)**** }\end{array}$ & $72(9,7 \%)$ & $550(73,9 \%)$ & $122(16,4 \%)$ & 12,91 & 0,02 \\
\hline Alkoholijuomat & $78(10,5 \%)$ & $567(76,2 \%)$ & $99(13,3 \%)$ & 2,29 & 0,00 \\
\hline
\end{tabular}

$*=\mathrm{p}<0.05 ; * * \mathrm{*}<0.01 ; * * * \mathrm{*}<0.001$

verrattuna aikaan ennen rajoitustoimia. Tilastollisesti merkitseviä eroja ilmeni kuitenkin kasvisten, palkokasvien, pähkinöiden, kalan, kasvisruokavaihtoehtojen, liha-, siipikarja-, kala- tai kasvisjalosteiden, täysjyväleivän, -pastan ja viljojen, makeiden ja suolaisten naposteltavien, kasvipohjaisten juomien sekä sokeroitujen juo- mien ryhmissä. Näiden ruoka-aineiden kohdalla tavallisempaa oli, että käyttöuseus oli rajoitusten aikana vähentynyt kuin että se oli lisääntynyt. Poikkeuksia olivat makeat ja suolaiset naposteltavat sekä sokeroidut juomat, joiden osalta raportoitiin enemmän entistä useampaa kuin entistä harvempaa käyttöä. 


\section{SOSIODEMOGRAFISTEN JA MUIDEN TAUSTATEKIJÖIDEN YHTEYS TERVEELLISISTÄ RAAKA-AINEISTA TEHTYJEN ATERIOIDEN VALMISTAMISEN JA ERI RUOKA-AINEIDEN KÄYTÖN USEUDEN MUUTOKSIIN}

Terveellisistä raaka-aineista tehtyjen aterioiden valmistamisen sekä ruoka-aineiden käytön useuden lisääntymistä tai vähentymistä kuvaavat mallit on esitetty taulukossa 3 . Ikä oli yhteydessä kasvisten käyttöuseuden vähenemiseen $(\mathrm{OR}=$ 1,378 CI $95 \%$ 1,08-1,75) siten, että kasvisten käyttöuseuden todennäköisyys kasvoi noin $38 \%$ kun ikäluokittelussa siirryttiin yhden luokan verran ylöspäin. Sen sijaan suolaisten naposteltavien käytön useuden muutokseen iällä oli toisen suuntainen yhteys: todennäköisyys sille, että vanhemmat vastaajat söivät aiempaa useammin suolaisia naposteltavia, oli noin $21 \%$ pienempi kuin nuorempien vastaajien $(\mathrm{OR}=0,787 \mathrm{CL}$ $95 \%$ 0,62-1,00). Koulutustaso ei ollut merkitsevä muuttuja yhdessäkään tarkastelluista malleista. Osa- tai kokoaikainen etätyö oli yhteydessä terveellisistä raaka-aineista tehtyjen aterioiden valmistamisen useuden lisääntymiseen mutta myös suolaisten naposteltavien käytön useuden lisääntymiseen kun verrattiin niihin, jotka eivät olleet työelämässä. Työssäkäynti kodin ulkopuolella vähensi todennäköisyyttä makeiden $(\mathrm{OR}=$ 0,487 CL $95 \%$ 0,25-0,96) ja suolaisten naposteltavien $(\mathrm{OR}=0,445 \mathrm{CI} 95 \% 0,20-0,99)$ sekä sokeroitujen juomien $(\mathrm{OR}=0,357 \mathrm{CI} 95 \%$ 0,16-0,80) käytön useuden lisääntymiseen verrattuna työelämän ulkopuolella oleviin. Tulotasonsa laskusta pandemian aikana raportoineet vastaajat olivat lisänneet suolaisten naposteltavien käyttöä todennäköisemmin $(\mathrm{OR}=1,741 \mathrm{CI}$ $95 \%$ 1,08-2,81) kuin ne, joiden tulotaso oli pysynyt ennallaan. Kotitaloustyyppi oli yhteydessä terveellisistä raaka-aineista tehtyjen aterioiden valmistamiseen siten, että todennäköisyys niiden valmistuksen useuden lisäämiseen oli pienempi lapsiperheissä $(\mathrm{OR}=0,481$ CI $95 \%$ 0,30-0,76) ja useamman aikuisen talouksissa $(\mathrm{OR}=0,506 \mathrm{CI}$ $95 \%$ 0,33-0,78) verrattuna yksin asuvien talouksiin. Tulosten mukaan näyttää lisäksi siltä, että mitä pidempään rajoitustoimet olivat kestäneet, sitä todennäköisemmin suolaisten naposteltavien käyttöuseus pieneni. Terveellisyyden huomioon ottaminen ruokavalinnoissa pandemia-aikana oli yhteydessä sekä kasvisten käytön useuden vähentymiseen että lisääntymiseen. Luottamus omiin taitoibin terveellisten aterioiden valmistamisessa puolestaan oli merkitsevä tekijä alkoholijuomien käytön useuden vähentämisessä mutta myös lisäämisessä. Koettu psyykkinen rasitus pandemian aikana oli merkitsevä tekijä makeiden naposteltavien $(\mathrm{OR}=1,19995 \%$ CI 1,02-1,41), sokeroitujen juomien $(\mathrm{OR}=1,28095 \% \mathrm{CI}$ 1,05-1,55) sekä alkoholijuomien (OR=1,655 95 \% CI 1,33-2,06) käytön useuden lisääntymisessä. Psyykkinen rasitus oli yhteydessä paitsi terveellisistä raaka-aineista tehtyjen aterioiden valmistamisen useuden vähentymiseen, myös sen lisääntymiseen.

\section{POHDINTA}

Tutkimuksessa tarkasteltiin terveyttä edistävän ruokakäyttäytymisen muutoksia Covid-19-pandemian aikana keskittyen erityisesti aterioiden valmistamiseen terveellisistä raaka-aineista sekä erilaisten ruoka-aineiden käyttöön. Havaintomme ovat monilta osin samansuuntaisia kansainvälisten tutkimusten tulosten kanssa. $\mathrm{Ne}$ ovat osoittaneet, että koronapandemian hillitsemiseksi asetettujen rajoitustoimien aikana syömisessä on monissa maissa tapahtunut sekä terveyttä edistäviä että sitä heikentäviä muutoksia, esimerkiksi aterioiden koossa ja säännöllisyydessä sekä epäterveellisten naposteltavien syönnissä (32, 33). Omat tuloksemme osoittavat, että niin erilaisten ruoka-aineiden käytön useudessa kuin terveellisistä raaka-aineista tehtyjen aterioiden valmistuksessa muutoksia on molempiin suuntiin. Useimmat vastaajat kuitenkin raportoivat, ettei muutoksia ollut rajoitustoimien käyttöönoton jälkeen tapahtunut. Samaa on havaittu kansainvälisestikin (20).

Sosiodemografisista taustatekijöistä ikä ja kotitaloustyyppi olivat yhteydessä muutoksiin joissakin esitetyistä ruoka-aineiden käyttöä ja terveellisistä raaka-aineista tehtyjen aterioiden valmistamista tarkastelleissa malleissa. Vastaajan korkeampi ikä lisäsi kasvisten käytön vähentämisen todennäköisyyttä mutta toisaalta myös vähensi suolaisten naposteltavien käytön lisääntymisen todennäköisyyttä verrattuna nuorempiin vastaajiin. Vanhemmilla vastaajilla pandemia-aika ei siten näytä samalla tavalla muuttaneen ruokatottumuksia epäterveellisempään suuntaan suolaisten naposteltavien osalta kuin nuoremmilla, vaikka kasvisten osalta näin tapahtui.

Noin runsas kolmasosa vastaajista raportoi valmistavansa terveellisistä raaka-aineista tehtyjä aterioita aikaisempaa useammin. Lapsiperheissä 


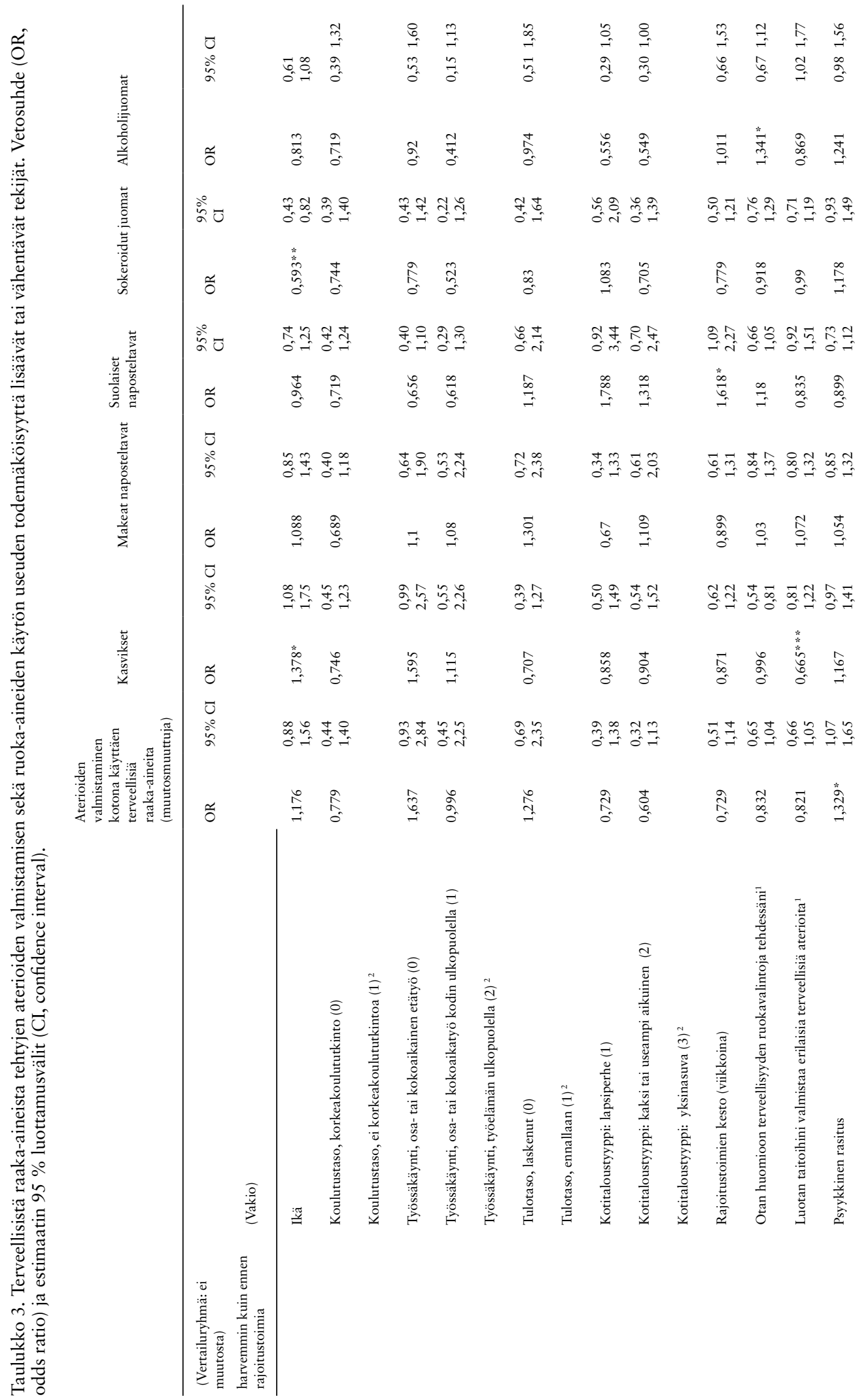




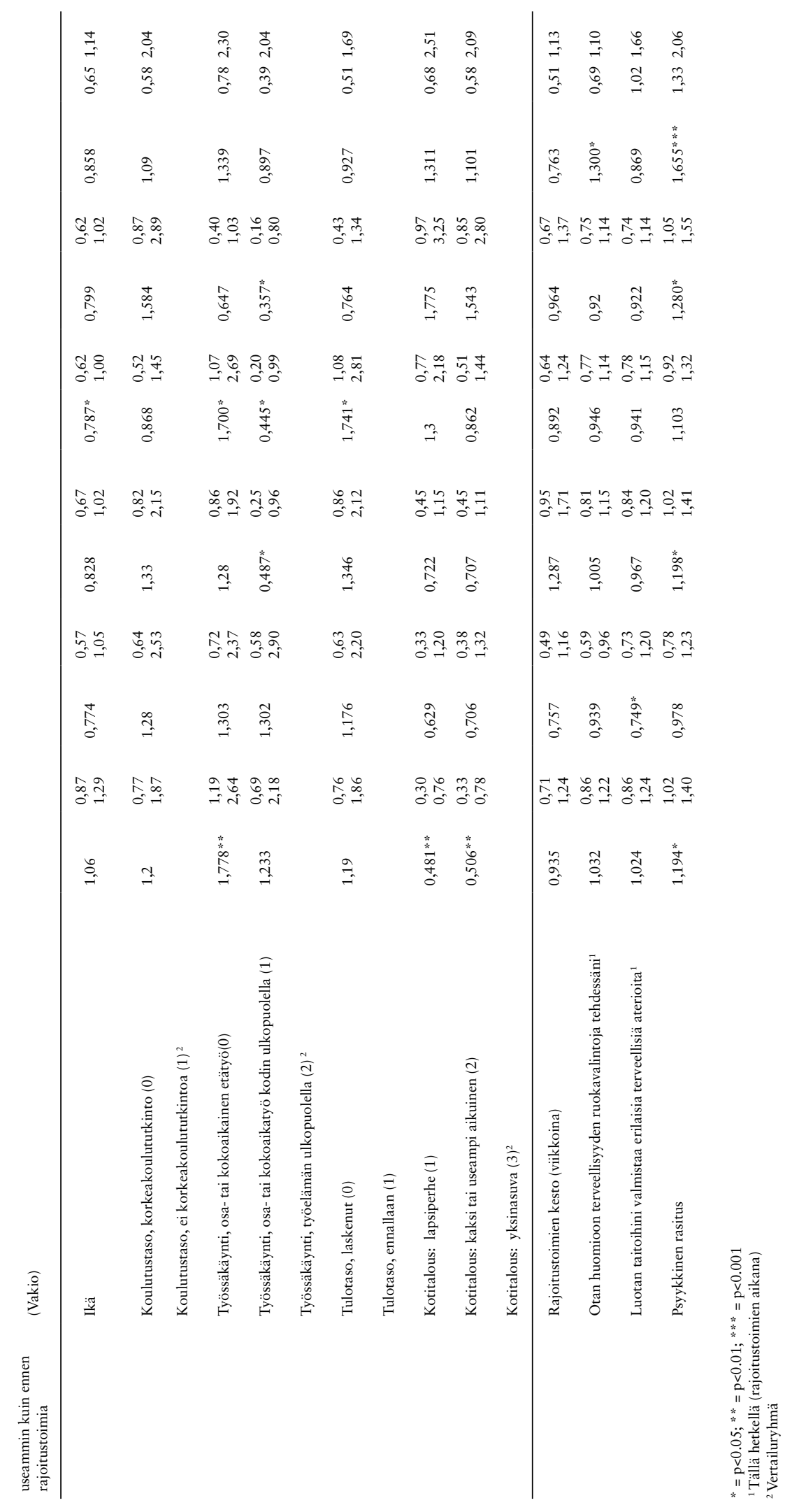


ja useamman kuin yhden aikuisen talouksissa terveellisistä raaka-aineista tehtyjen aterioiden valmistamisen lisääntyminen oli vähemmän todennäköistä verrattuna yksin asuviin. Sen sijaan kotitaloustyyppi ei ollut yhteydessä tarkasteltujen ruoka-aineiden käytön useuden muutokseen. On kuitenkin huomattava, että terveellisistä raaka-aineista tehtyjen aterioiden valmistamisen useuden muutokset eivät välttämättä kerro aterioiden laadun muutoksesta tai raaka-aineiden vaihtamisesta terveellisempään tai epäterveellisempään suuntaan. Osa vastaajista on voinut esimerkiksi kokea valmistaneensa ateriat jo ennen koronapandemiaa terveellisistä raaka-aineista, mutta etätyön vuoksi näitä on valmistettu aikaisempaa useammin. Näin ollen tulosten osoittamat muutokset voivat kertoa joko siitä, että aterioiden valmistamisen useus on korona-aikana muuttunut tai vaihtoehtoisesti siitä, että terveellisistä raaka-aineista valmistettujen aterioiden määrä on muuttunut. Kysymyksenasettelu ei mahdollista sen arviointia, kummasta on kunkin vastaajan kohdalla kysymys.

Kuten aikaisemmin on mainittu, koulutus ei ollut malleissa tilastollisesti merkitsevä, mikä saattaa selittyä sillä, että vastaajat olivat valtaosin korkeasti koulutettuja. Viiden malleihin valitun ruoka-aineen - kasvisten, makeiden naposteltavien, suolaisten naposteltavien, sokeroitujen juomien ja alkoholijuomien - käytön sekä terveellisistä raaka-aineista valmistettujen aterioiden valmistamisen useuden muutoksia rajoitustoimien aikana selittivät erityisesti psyykkinen rasitus ja etätyö. Pandemian aikainen psyykkinen rasitus oli yhteydessä sekä terveellisistä raakaaineista tehtyjen aterioiden valmistamisen useuden lisääntymisen että vähentymisen todennäköisyyteen. Psyykkinen rasitus näyttää voivan kanavoitua niin pyrkimyksiin valmistaa aterioita terveellisistä raaka-aineista kuin näiden valmistamiseksi tarvittavien voimavarojen heikkenemiseen. Corona Cooking Survey -hankkeen 38 maan aineistoon perustuvassa tutkimuksessa osoitettiin, että terveellisistä raaka-aineista valmistettujen aterioiden tekemisen useus keskimäärin lisääntyi (29). Psyykkinen rasitus oli myös yhteydessä sokeripitoisten naposteltavien käytön useuden lisääntymiseen. Sokeripitoinen ruoka voi toimia stressaavassa tilanteessa lohturuokana, mutta makeiden naposteltavien kulutuksen lisääntyminen voi myös olla osoitus rutiinien katoamisesta 34-36). Tuoreen tutkimuksen mukaan tunnesyömisen lisääntyminen pandemian rajoitustoimien aikana oli yhteydessä korkeampaan painoindeksiin, jo aiempaan tunnesyömisen taipumukseen ja huonoon elämänhallintaan (37). Lisäksi makeiden naposteltavien käytön useuden lisääntyminen voi olla osoitus siitä, että aikaisemmin kodin ulkopuolella tapahtunut työtai opiskeluaikainen erilaisten ruokapalvelujen mahdollistama säännöllinen ruokailu on poikkeusoloissa saattanut muuttua epäsäännölliseksi ja voinut lisätä epäsäännöllisten välipalojen ja naposteltavien syömistä (esim. 38). Voi myös olla, että koti on ympäristö, joka mahdollistaa makeiden naposteltavien nauttimisen paremmin kuin työ- tai opiskelupaikka.

On kiinnostava tulos, että erityisesti yksin asuvilla terveellisistä raaka-aineista tehtyjen aterioiden valmistaminen kotona lisääntyi suhteessa enemmän kuin lapsiperheissä. Tätä tulosta voisi tulkita siten, että lapsiperheillä ruoan valmistaminen on osa kotitalouden toimintaa pandemiasta riippumatta, mutta yksin asuvan elämäntyylissä erilaisten ruokapalvelujen tarjoamat kodin ulkopuolella nautitut ateriat saattavat olla pääasiallinen ateriointitapa. Näin ollen pandemian rajoitustoimien aiheuttama ravintoloiden kiinniolo vaikutti mahdollisesti enemmän yksinasuvien kuin lapsiperheiden arkiseen ruoanlaittoon. Rajoitusten aikana tehdyt selvitykset antavat viitteitä siitä, että lapsiperheissä voitiin terveellisistä raaka-aineista valmistettujen aterioiden valmistamisen sijaan ostaa enemmän valmisruokia (12) tai korvata aterioita helpoilla ja nopeilla suolaisilla ja makeilla naposteltavilla (38). Voidaan myös pohtia, valmistivatko vanhemmat itse asiassa enemmän aterioita pandemian aikana (mahdollisen lounaan tai päivällisen lisäksi), joita he eivät kuitenkaan voineet subjektiivisesti arvioida terveellisiksi kyselyyn vastatessaan.

Etätyö oli yhteydessä terveellisistä raaka-aineista tehtyjen aterioiden valmistamisen lisääntymiseen, mutta myös suolaisten naposteltavien käytön lisääntymiseen verrattuna niihin, jotka eivät olleet tutkimushetkellä töissä. Toisaalta rajoitustoimien kesto oli merkitsevä suolaisten naposteltavien vähentymisessä. Kuten aiemmin todettiin makeiden naposteltavien lisääntymisen osalta, on mahdollista, että myös suolaisten naposteltavien käytön lisääntyminen johtuu arjen rutiinien uudesta ajallisesta järjestymisestä. Ruo- 
kailurytmi on voinut muuttua, kun aikaisemmin työpäivien aikana kodin ulkopuolella tapahtunut säännöllinen ruokapalvelujen käyttö ei ollut mahdollista. Näin ollen voidaan olettaa, että rajoitustoimien alkuvaiheessa, kun poikkeusolot olivat uutta ja kotona vietettiin yllättäen enemmän aikaa, suolaisten naposteltavien kulutus aluksi lisääntyi. Poikkeusolojen jatkuessa kulutus kuitenkin vähitellen tasaantui kenties uusien ruoanlaittorutiinien myötä. Tässä tutkimuksessa ei kysytty ruokailurytmistä ja sen ylläpitämisestä, jonka voidaan olettaa olevan vaikeaa, jos kollektiiviset syömisen käytännöt ja niihin liittyvät aikataulut muuttuvat. (esim. 39-41.)

Myös stressi ja psyykkinen rasitus voivat muuttaa ruokailurytmiä ja lisätä epäsäännöllistä napostelua $(42,43)$. Lisääntynyt psyykkinen rasitus yhdistettynä etätyöhön voi aiheuttaa sen, että lounasaika vietetään joko yksin tai työn ääressä tai että päivän aikana ei ole mahdollista pitää ruokataukoa lainkaan, jolloin lounas korvataan helposti nautittavalla välipalatuotteella tai naposteltavalla (vrt.1). Suolaisten naposteltavien käytön lisääntymisen todennäköisyyttä lisäsi myös tulotason lasku. Tulojen väheneminen voi liittyä työttömäksi tai lomautetuksi jäämiseen, mikä saattaa muuttaa ruokatottumuksia epäterveellisemmiksi (44). Kodin ulkopuolella työssäkäyvillä puolestaan makeiden ja suolaisten naposteltavien sekä sokeroitujen juomien käytön lisääntyminen oli vähemmän todennäköistä kuin niillä, jotka eivät olleet tutkimushetkellä työelämässä. Työssäkäynti kodin ulkopuolella vaikuttaakin olevan yksi merkittävä tekijä terveyttä edistävässä ruokakäyttäytymisessä, sillä esimerkiksi henkilöstöravintoloissa on usein tarjolla ravitsemussuositusten mukaisia ateriakokonaisuuksia.

Tulos alkoholijuomien käytön vähenemisestä on linjassa aikaisemman tutkimuksen kanssa, jonka mukaan $80 \%$ suomalaisista ei muuttanut alkoholinkulutustaan pandemian aikana (45). Vaikka pandemian alkuvaiheessa alkoholin käytön lisääntymistä pidettiin mahdollisena, tutkimukset ovat osoittaneet, että sen käyttö jopa väheni (46). Samaa on havaittu kansainvälisissä tutkimuksissa (32). Kiinnostavaa on, että luottamus omiin taitoihin terveellisistä raaka-aineista tehtyjen aterioiden valmistamisessa lisäsi todennäköisyyttä sekä alkoholin käytön lisääntymi- seen että vähentämiseen. Selitys on epävarma, mutta saattaa olla, että yhtäältä osa terveellisen ruoanlaiton taitavista ihmisistä on käyttänyt ravintoloiden ollessa kiinni tavallista vähemmän alkoholia, toisaalta osa on ehkä valmistanut aikaisempaa enemmän ruokaa ja käyttänyt kotona nautittujen aterioiden yhteydessä alkoholia tavallista useammin. Vastaavasti terveellisyyden huomioon ottaminen ruokavalinnoissa rajoitustoimien aikana pienensi sekä kasvisten käytön vähentämisen että lisäämisen todennäköisyyttä. Edellinen yhteys on johdonmukainen, sillä on uskottavaa, että terveellisyyden huomioon ottavat eivät rajoitustoimien aikanakaan vähentäneet kasvisten käyttöä verrattuna niihin, jotka ylipäätään kiinnittävät terveellisyyteen vähemmän huomiota. Samalla näyttää siltä, että ne, jotka kiinnittävät terveellisyyteen vähemmän huomiota, ovat kuitenkin todennäköisemmin lisänneet kasvisten käyttöä. Mahdollisesti poikkeusoloissa lisääntynyt kotiruoanlaitto on heillä lisännyt kasvisten käyttöä, vaikka terveellisyys ei olisikaan tärkeä ruoan valinnan motivaatio.

Edellä esitetyn perusteella epäterveellinen syöminen rajoitustoimien aikana vaikuttaisi olevan todennäköisintä nuorilla, etätyössä olevilla, psyykkistä rasitusta kokevilla ja niillä, joiden taloudellinen tilanne on pandemian alettua heikentynyt. Tämä on uskottavaa, sillä rajoitustoimet ovat saattaneet vaikuttaa erityisesti nuorten elämän rutiineihin merkittävästi esimerkiksi opiskelun, harrastustoiminnan ja sosiaalisia kontakteja koskeneiden rajoitusten osalta. Terveellinen syöminen puolestaan vaikuttaisi olevan todennäköisintä vanhemmilla ihmisillä, yksinasuvilla ja niillä, jotka käyvät töissä kodin ulkopuolella. Etätyö, psyykkinen rasitus ja tulojen niukkeneminen voivat muuttaa ruoanlaittoon ja syömiseen liittyviä rutiineja ja siten vaikuttaa myös syömisen terveellisyyteen.

Käyttämässämme tutkimusaineistossa on rajoitteita, jotka tulee ottaa huomioon tulosten tulkinnassa ja yleistämisessä. Aineisto on kerätty kutsumalla sosiaalisen median kanavien ja sähköpostin kautta kiinnostuneita ihmisiä osallistumaan kyselyyn. Kyse ei siten ole edustavasta otoksesta. Korkeakoulutetut naiset ovat usein erilaisissa kyselyissä yliedustettuna, niin myös tässä. Aineiston naisvaltaisuuden vuoksi sukupuolten välisiä eroja ei ollut tässä tutkimuksessa mah- 
dollista tarkastella. Aikaisemman kirjallisuuden perusteella voidaan todeta, että vaikka naiset kantavat edelleen useimmiten päävastuun kotitalouden ruokatyöstä, sukupuolten välinen ero työnjaossa on kaventunut (47). Aineiston lähes kaikki miesvastaajat ilmoittivat tekevänsä itse ruokaostoksia ja laittavansa ruokaa. Ylipäätään kiinnostus ruokaan on voinut ohjata tutkimukseen osallistuvia vastaamaan, eikä kysely ole välttämättä tavoittanut niitä, jotka eivät ole ruoasta tai ruoanlaitosta erityisen kiinnostuneita. Tutkimuksen aineiston heikkous on myös se, että raportoidut muutokset perustuvat vastaajien omiin arviointeihin menneistä tapahtumista, eikä vastaajia pyydetty raportoimaan ruoan käyttöä täsmällisesti jonakin tiettynä ajanjaksona. Myöskään eri vuodenaikoihin liittyvää käytön useutta ei ollut mahdollista eritellä. Lisäksi kansainvälisen kyselylomakkeen sisältämiä kysymyksiä ei voitu muuttaa eikä jättää pois, joten erilaisia suomalaiselle ruokakulttuurille ominaisia piirteitä, kuten työpaikkaruokailua, ei pystytty huomioimaan. Aineiston maantieteellistä jakaumaa ei myöskään ollut mahdollista selvittää, koska kysymys asuinpaikasta puuttui lomakkeelta.

Tämän tutkimuksen osallistujien vastausten perusteella ei voida tehdä yleistyksiä siitä, millaisia elämänmuutoksia, kokemuksia ja syömisen muutoksia koronapandemia on käynnistänyt suomalaisen väestön keskuudessa. Tulosten perusteella voidaan kuitenkin sanoa, että rajoitustoimien aikana koettu psyykkinen rasitus ja etätyöhön siirtyminen ovat olleet yhteydessä ruokavalintoihin ja että pandemian aikaiset rajoitustoimet muuttavat syömistottumuksia eri tavoin erilaisissa kotitalouksissa. Tulokset siten osaltaan dokumentoivat kiinnostavasti poik- keustilannetta, jollaista Suomessa ei ole ollut sitten toisen maailmansodan. Jatkossa tarvitaan väestöä edustavaan aineistoon perustuvaa tutkimusta ruokaan liittyvien valintojen, tottumusten ja käytäntöjen muutoksista ja niiden esiintymisestä eri väestöryhmissä, jotta tarvittavia ruokaja ravitsemuspoliittisia toimia voidaan suunnata oikein.

\section{KIITOKSET:}

Kansainvälisen Corona Cooking Survey -hankkeen käynnistivät, suunnittelivat ja koordinoivat hankkeen johtaja professori Charlotte De Backer sekä Lauranna Teunissen, Isabelle Cuykx, Paulien Decorte, Sara Pabian ja Kathleen Van Royen. Kiitämme lämpimästi professori De Backeria mahdollisuudesta osallistua hankkeeseen ja kerätä Suomen Corona Cooking Survey -aineisto sen osana. Samalla esitämme parhaat kiitoksemme kahdelle anonyymille arvioijalle poikkeuksellisen huolellisista ja rakentavista kommenteista, joista oli suurta hyötyä tekstin muokkauksessa ja viimeistelyssä.

\section{RAHOITTAJAT:}

Helsingin yliopiston kestävyystieteen instituutin rahoittama hanke "Embedding environmental sustainability norms in society" (Embed).

\section{KIRJOITTAJIEN KONTRIBUUTIOT:}

Kaikki kirjoittajat osallistuivat tutkimuksen suunnitteluun, aineiston keräämiseen ja tulosten tulkintaan. Salmivaara vastasi aineiston analyysista ja oli päävastuussa artikkelista. Kaikki kirjoittajat ovat osallistuneet käsikirjoituksen kirjoittamiseen, vaikuttaneet sen sisältöön, hyväksyneet sen ja ottavat vastuun artikkelin kaikista osa-alueista.

Salmivaara, L., Niva, M., Torkkeli, K., Mäkelä, J., Vainio, A. Changes in food choices during the COVID-19 pandemic: Results of the international Corona Cooking Survey in Finland. Sosiaalilääketieteellinen aikakauslehti - Journal of Social Medicine 202 I : 58: 304-3 19.

The COVID-19 pandemic lockdown measures has changed people's everyday practices in many ways. In this article, we investigate the changes in food consumption and preparation of meals at home using healthy ingredients during the spring 2020 COVID-19 restrictions in Finland, and how socio-economic and other background factors, such as psychological distress and remote work, were linked to the changes.
The data were based on a survey on eating and cooking collected in the international Corona Cooking Survey project. A total of 744 adults (aged 19-85) living in Finland responded to the survey shared via social media in May-June 2020. The sample was not statistically representative of the Finnish population, as the majority of the respondents were women $(91 \%)$ and had an academic (equivalent to at least Bachelor's) degree 
$(81 \%)$. In this article, we describe the changes reported by the respondents in the frequency of eating 19 foods and cooking meals at home using healthy ingredients. In multinomial logistic regression models, we investigate changes in cooking meals at home using healthy ingredients and in consuming five foods, as well as factors that are associated with the changes.

For all foods analyzed, more than half of the respondents reported that they had not changed their consumption. Largest increases in consumption frequencies were reported for sweet snacks $(29 \%$ of the respondents reported to eat more frequently) and salty snacks $(21 \%)$ as well as white bread, pasta and grains $(21 \%)$. Largest decreases were reported in the frequency of using processed meat/poultry/fish/vegetarian alternatives $(34 \%)$, legumes $(29 \%)$ and nuts $(27 \%)$. According to the results of the regression models, most background factors were not associated with the changes. The explanatory factors varied between the foods/drinks examined. Psychological distress increased the likelihood of consuming sweet snacks, sugary drinks and alcoholic drinks more often during the restrictions than before. Working at home increased the likelihood of eating less vegetables and more salty snacks, but it also increased the likelihood of cooking meals using healthy ingredients more often than before the restrictions. The results suggest that snacking increased during the restrictions. Further research with representative samples of the Finnish population is needed on potential longer-term changes in eating routines and their possible transformation into healthier or unhealthier habits in different population groups.

Keywords: Covid-19 restrictions, Covid-19 pandemic, food choice, survey

$$
\begin{gathered}
\text { Saapunut }(11.03 .2021) \\
\text { Hyväksytty }(23.08 .2021)
\end{gathered}
$$

\section{LÄHTEET}

1. Ruohomäki V. Etätyöloikka ja hyvinvointi koronakriisin alussa. Työpoliittinen aikakauskirja $2020 ; 21$

2. Eurofound. Living, working and COVID-19, COVID-19 series. Publications Office of the European Union, Luxembourg; 2020

3. Opetus-ja kulttuuriministeriö, Sosiaali-ja terveysministeriö, Valtioneuvoston viestintäosasto. Hallitus on todennut yhteistoiminnassa tasavallan presidentin kanssa Suomen olevan poikkeusoloissa koronavirustilanteen vuoksi. Tiedote 16.3.2020. Luettu 9.2.2021. https://valtioneuvosto.fi/-/10616/ hallitus-totesi-suomen-olevan-poikkeusoloissakoronavirustilanteen-vuoksi

4. Työ- ja elinkeinoministeriö. Ravintolat sulkeutuvat asiakkailta, ruokaa voi kuitenkin tilata ja noutaa. Tiedote 24.3.2020. Luettu 9.2.2021. https:// valtioneuvosto.fi/-/1410877/ravintolat-sulkeutuvatasiakkailta-ruokaa-voi-kuitenkin-tilata-ja-noutaa

5. Anttinen M, Hakola-Uusitalo T, Heinonen M, ym. Koronakriisin vaikutus kotitalouksiin. Kilpailu- ja kuluttajaviraston selvityksiä 1/2020. https://www.kkv.fi/globalassets/kkv-suomi/ julkaisut/selvitykset/2020/kkv-selvityksia-1-2020koronakriisin-vaikutus-kotitalouksiin.pdf

6. Attwood S, Hajat C. How will the COVID-19 pandemic shape the future of meat consumption? Public Health Nutr 2020;23(17):3116-3120. doi: 10.1017/S136898002000316X

7. Bracale R, Vaccaro CM. Changes in food choice following restrictive measures due to Covid-19. Nutr Metab Cardiovasc Dis 2020;30(9):1423-
1426.

doi: 10.1016/j.numecd.2020.05.027

8. Naja F, Hamadeh R. Nutrition amid the COVID-19 pandemic: a multi-level framework for action. Eur J Clin Nutr 2020;74(8):1117-1121. doi: 10.1038/s41430-020-0634-3

9. Raulio, S., Roos, E. Työaikaisen aterioinnin väestöryhmäerot ja yhteys ruokavalion laatuun. Sosiaalilääk Aikak 2012;49(2):140-148.

10. Cavallo C, Sacchi G, Carfora V. Resilience effects in food consumption behaviour at the time of Covid-19: perspectives from Italy. Heliyon 2020;6(12):e05676. doi: 10.1016/j.heliyon.2020.e05676

11. Hirvonen T, Loukkola, P. Ensin Suomi hamstrasi vessapaperia ja säilykkeitä, nyt maistuu olut, suklaa ja jäätelö - grafiikat kertovat, mitä nyt ostamme. Yle; 2020. Uutinen 26.3.2020. https://yle.fi/uutiset/3-11271079

12. EIT food. COVID-19 impact on consumer food behaviours in Europe. 2020. Luettu 12.5.2021. https://www.eitfood.eu/media/ documents/COVID-19_Study_-_European_Food_ Behaviours_-_Report.pdf

13. Latvala, T., Väre, M., Niemi, J. (toim.) Maaja elintarviketalouden suhdannekatsaus 2020. Luonnonvara-ja biotalouden tutkimus 33/2020. Helsinki: Luonnonvarakeskus; 2020. https://jukuri.luke.fi/handle/10024/545930

14. Marty L, de Lauzon-Guillain B, Labesse M, Nicklaus S. Food choice motives and the nutritional quality of diet during the COVID-19 
lockdown in France. Appetite 2021;157. doi: 10.1016/j.appet.2020.105005

15. Giacalone D, Frøst MB, Rodríguez-Pérez C, AGR141 Research Group. Reported Changes in Dietary Habits During the COVID-19 Lockdown in the Danish Population: The Danish COVIDiet Study. Front Nutr 2020;7. doi: 10.3389/fnut.2020.592112

16. Sidor A, Rzymski P. Dietary choices and habits during COVID-19 lockdown: Experience from Poland. Nutrients 2020;12(6). doi: 10.3390/nu12061657

17. Ammar A, Brach M, Trabelsi K, Chtourou $\mathrm{H}$, Boukhris O, Masmoudi L, ym. Effects of COVID-19 Home Confinement on Eating Behaviour and Physical Activity: Results of the ECLB-COVID19 International Online Survey. Nutrients [Internet]. MDPI AG; 2020 May 28;12(6):1583. doi: 10.3390/nu12061583

18. Scarmozzino F, Visioli F. Covid-19 and the subsequent lockdown modified dietary habits of almost half the population in an Italian sample. Foods 2020;9(5). doi: 10.3390/foods 9050675

19. Di Renzo LD, Gualtieri P, Cinelli G, Bigioni G, Soldati L, Attinà A, et al. Psychological aspects and eating habits during covid-19 home confinement: Results of ehlc-covid-19 italian online survey. Nutrients 2020;12(7):1-14. doi: $10.3390 / \mathrm{nu} 1207215$

20. Herle M, Smith A D, Bu F, ym. Trajectories of eating behavior during COVID-19 lockdown: Longitudinal analyses of 22,374 adults.Clinical Nutrition ESPEN 2021;42:15

21. Roitblat Y, Burger J, Leit A, Nehuliaieva L, Umarova GS, Kaliberdenko V, ym. Stay-at-home circumstances do not produce sleep disorders: An international survey during the COVID-19 pandemic. J Psychosom Res 2020;139. doi: 10.1016/j.jpsychores.2020.110282

22. Kestilä L, Härmä V, Rissanen P. Covid19epidemian vaikutukset hyvinvointiin, palvelujärjestelmään ja kansantalouteen: Asiantuntija-arvio, syksy 2020. Terveyden ja hyvinvoinnin laitos Raportti 14, 2020. https:// www.julkari.fi/bitstream/handle/10024/140661/ URN_ISBN_978-952-343-578-0.pdf

23. Jousilahti P, Borodulin K, Härkänen T, ym. Koronapandemian ja torjuntatoimien vaikutukset aikuisväestön työmatka- ja vapaa-ajan liikuntaan. Koronapandemian vaikutukset väestön liikuntaan. Valtion liikuntaneuvoston julkaisuja. 2020;2:21-26. Luettu 8.3.2021. https://www. liikuntaneuvosto.fi/wp-content/uploads/2020/10/ Koronapandemian-vaikutukset-vaeston-liikuntaanpaivitetty-23.11.2020.pdf

24. Ranta M, Silinskas G, Wilska T. Young adults' personal concerns during the COVID-19 pandemic in Finland: an issue for social concern. Int $\mathrm{J}$ of Sociology and Social Policy 2020;(40);9/10:12011219.

doi: 10.1108/IJSSP-07-2020-0267
25. Honkatukia J, Härmä V, Jormanainen V, ym. Koronaepidemian vaikutukset hyvinvointiin, palveluihin ja talouteen. Terveyden ja hyvinvoinnin laitos viikkoraportti 24, 2020. Luettu 10.6.2020. https://www.julkari.fi/bitstream/ handle/10024/139889/Viikko\%2024-2020\%20 -\%20Koronaepidemian \%20vaikutukset $\% 20$ hyvinvointiin $\% 2 \mathrm{C} \% 20$ palveluihin $\% 20 \mathrm{ja} \% 20$ talouteen.pdf

26. Newby JM, O’Moore K, Tang S, Christensen H, Faasse K. Acute mental health responses during the COVID-19 pandemic in Australia. PLoS ONE 2020;15(7);e0236562. doi: 10.1371/journal.pone.0236562

27. Bemanian M, Mæland S, Blomhoff R, ym. Emotional Eating in Relation to Worries and Psychological Distress Amid the COVID-19 Pandemic: A Population-Based Survey on Adults in Norway. Int. J. Environ. Res. Public Health 2021;18(1):130. doi: 10.3390/ijerph18010130

28. Gonçalves PD, Moura HF, do Amaral RA, ym. Alcohol Use and COVID-19: Can we Predict the Impact of the Pandemic on Alcohol Use Based on the Previous Crises in the 21st Century? A Brief Review. Front Psychiatry 2020;11:1456. doi: 10.3389/fpsyt.2020.581113

29. De Backer C, Teunissen L, Cuykx I, ym. An Evaluation of the COVID-19 Pandemic and Perceived Social Distancing Policies in Relation to Planning, Selecting, and Preparing Healthy Meals: An Observational Study in 38 Countries Worldwide. Front Nutr 2020;7. doi: 10.3389/fnut.2020.621726

30. Kessler RC, Andrews G, Colpe LJ, ym. Short screening scales to monitor population prevalences and trends in non-specific psychological distress. Psychol Med 2002;32(6):959-976. doi: $10.1017 /$ S0033291702006074

31. Valtion ravitsemusneuvottelukunta. Terveyttä ruoasta. Suomalaiset ravitsemussuositukset 2014 Helsinki: Valtion ravitsemusneuvottelukunta. Luettu 14.5.2021. https://www.ruokavirasto.fi/ globalassets/teemat/terveytta-edistava-ruokavalio/ kuluttaja-ja-ammattilaismateriaali/julkaisut/ ravitsemussuositukset_2014_fi_web_versio_5.pdf.

32. Pišot S, Milovanović I, Šimunič B, ym. Maintaining everyday life praxis in the time of COVID-19 pandemic measures (ELP-COVID-19 survey). Eur J Public Health 2020;30(6):11811186.

doi: 10.1093/eurpub/ckaa157

33. Gerritsen S, Egli V, Roy R, ym. Seven weeks of home-cooked meals: changes to New Zealanders' grocery shopping, cooking and eating during the COVID-19 lockdown. J R Soc N Z 2020;1-19. doi: 10.1080/03036758.2020.1841010

34. Oliver G, Wardle J, Gibson EL. Stress and food choice: A laboratory study. Psychosom Med 2000;62(6):853-865. doi: 10.1097/00006842-200011000-00016

35. Smith KR, Jansen E, Thapaliya G, Aghababian AH, Chen L, Sadler JR, ym. The influence of COVID-19-related stress on food motivation. 
Appetite 2021;163.

doi: 10.1016/j.appet.2021.105233

36. Wallis DJ, Hetherington MM. Emotions and eating. Self-reported and experimentally induced changes in food intake under stress. Appetite 2009;52(2):355-362.

doi: 10.1016/j.appet.2008.11.007

37. Coulthard H, Sharps M, Cunliffe L, ym. Eating in the lockdown during the Covid 19 pandemic; self-reported changes in eating behaviour, and associations with BMI, eating style, coping and health anxiety. Appetite 2021;161:105082. doi: 10.1016/j.appet.2020.105082

38. Jansen E, Thapaliya G, Aghababian A, ym. Parental stress, food parenting practices and child snack intake during the COVID-19 pandemic. Appetite 2021;161.

doi: 10.1016/j.appet.2021.105119

39. Lund T B, Gronow J. Destructuration or continuity? The daily rhythm of eating in Denmark, Finland, Norway and Sweden in 1997 and 2012. Appetite 2014;82:143-153. doi: 10.1016/j.appet.2014.07.004

40. Bjerre N, Holm L, Quist J S, ym. Watching, keeping and squeezing time to lose weight: Implications of time-restricted eating in daily life. Appetite 2021;161.

doi: 10.1016/j.appet.2021.105138

41. Laatikainen T, Vapalahti O, Kalland M, ym. COVID-19-kriisin haitallisten vaikutusten ehkäiseminen kestävän kehityksen periaatteiden mukaisesti: Valtioneuvoston COVID19tiedepaneelin vastaukset valmisteluryhmän kysymyksiin. 2020; Valtioneuvoston kanslia.

42. O'Connor DB, Jones F, Conner M, ym. Effects of daily hassles and eating style on eating behavior. Health Psychol. 2008; 27;S20-S31. doi: 0.1037/0278-6133.27.1(Suppl.).S20

43. O’Connor DB, Conner M. Effects of stress on eating behavior. In: Richard J. Contrada, Andrew Baum (eds.) The handbook of stress science: Biology, psychology, and health. Springer Publishing Company, New York; 2011. 275-286.

44. Spinosa J, Christiansen P, Dickson JM, ym. From socioeconomic disadvantage to obesity: the mediating role of psychological distress and emotional eating. Obesity 2019;27(4);559-564. doi: 10.1002/oby.22402

45. Mäkelä P, Warpenius K, Keski-Kuha T, ym. Koronaepidemian vaikutukset suomalaisten alkoholinkulutukseen vuonna 2020. Helsinki: Terveyden ja hyvinvoinnin laitos; 2020. https://www.julkari.fi/handle/10024/141146

46. Mäkelä P, Ylöstalo T, Warpenius K, ym. Koronaepidemian vaikutukset suomalaisten alkoholinkulutukseen: kokonaisarvio kevään ja kesän 2020 muutoksista. Tutkimuksesta tiiviisti 30/2020. Helsinki: Terveyden ja hyvinvoinnin laitos; 2020.

47. Holm L, Ekström MP, Hach S, ym. Who is cooking dinner? Changes in the gendering of cooking from 1997 to 2012 in four Nordic countries. Food, Culture \& Society 2015;18(4);589-610. doi: $10.1080 / 15528014.2015 .1088191$

\section{LAURA SALMIVAARA \\ ETT, tutkijatohtori \\ Helsingin yliopisto \\ Helsingin yliopiston kestävyystieteen instituutti (HELSUS) \\ Metsätieteiden osasto}

\author{
MARI Niva \\ FT, dosentti, professori \\ Helsingin yliopisto \\ Taloustieteen osasto \\ Helsingin yliopiston kestävyystieteen instituutti \\ (HELSUS)
}

\section{KAISA TORKKELI \\ KM, tohtorikoulutettava \\ Helsingin yliopisto \\ Kasvatustieteiden osasto}

JOHANNA MÄKELÄ

VTT, dosentti, professori

Helsingin yliopisto

Kasvatustieteiden osasto

ANNUKKa VAINio

VTT, dosentti, apulaisprofessori

Helsingin yliopisto

Helsingin yliopiston kestävyystieteen instituutti (HELSUS)

Metsätieteiden osasto 